\title{
Angiotensin-converting enzyme inhibitory activity of polyphenolic compounds from Peperomia pellucida (L) Kunth: An in silico molecular docking study
}

\author{
Islamudin Ahmad ${ }^{1 *}$, Azminah $^{2,4}$, Kamarza Mulia $^{3}$, Arry Yanuar $^{4}$, Abdul Mun'im $^{4 *}$ \\ ${ }^{1}$ Department of Pharmaceutical Sciences, Faculty of Pharmacy, Mulawarman University, Samarinda, East Kalimantan, Indonesia. \\ ${ }^{2}$ Faculty of Pharmacy, University of Surabaya, Surabaya, East Java, Indonesia. \\ ${ }^{3}$ Department of Chemical Engineering, Faculty of Engineering, Universitas Indonesia, Depok, West Java, Indonesia. \\ ${ }^{4}$ Department of Pharmaceutical Sciences, Faculty of Pharmacy, Universitas Indonesia, Depok, West Java, Indonesia.
}

\section{ARTICLE INFO \\ Received on: 21/04/2019 \\ Accepted on: 13/05/2019 \\ Available online: 03/08/2019}

\section{Key words:}

Angiotensin-converting enzyme, binding affinity, molecular docking, Peperomia pellucida (L) Kunth, polyphenolics.

\section{ABSTRACT}

This study aimed to predict the potential activity and interaction conformation of polyphenolic compounds from Peperomia pellucida (L) Kunth (nine compounds) with angiotensin-converting enzyme (ACE) macromolecule by in silico molecular docking study. The crystal structure of ACE as a molecular target was obtained from the PDB database (PDB ID: 1UZF) with captopril as a native ligand. Molecular docking analysis was performed using AutoDockZn (100 docking runs) based on the active site of $\mathrm{Zn}^{2+}$, the central grid was placed on $\mathrm{Zn}^{2+}$ with a box size of $40 \mathrm{~A} \times 40 \mathrm{~A} \times$ $40 \hat{A}$ and a center of $40.835 \hat{A} \times 34.382 \hat{A} \times 44.607 \hat{A}$ for selective inhibitors (MCO702) with a spacing of 0.375Á. Based on the docking results demonstrated that the prediction of each polyphenol compounds from P. pellucida has the potential of active as ACE inhibitors, it was indicated that docking results of each compound has lower affinity compared to captopril (with binding affinity of $-6.36 \mathrm{kcal} / \mathrm{mol}$ and the inhibition constant $21.81 \mu \mathrm{M}$ ), where the most moderate binding affinity (the most potential) was tetrahydrofuran lignin ((1R,2S,3S,5R)-3,5-bis(4-hydroxy3,5-dimethoxyphenyl)cyclopentane-1,2-diyl)bis-(methylene) diacetate) of $-8.66 \mathrm{kcal} / \mathrm{mol}$ and the highest binding affinity (the less potential) was dillapiole (6-allyl-4,5-dimethoxybenzo[d][1,3]dioxole) of $-4.99 \mathrm{kcal} / \mathrm{mol}$, although with different forms of interaction, bond, and constant inhibition. Based on the interaction of ACE binding site, 5,6,7-trimethoxy-4-(2,4,5-trimethoxyphenyl)-3,4-dihydronaphthalen-1(2H)-one showed the most similar interaction with the captopril ligand. These results are preliminary data for further research with predictions of target compound biological activity and interaction quickly, accurately, and inexpensively.
\end{abstract}

\section{INTRODUCTION}

Hypertension or high blood pressure is one of the most top prevalent diseases in the world (Sorlie et al., 2014). In 2010, it was estimated $31.1 \%$ of adults worldwide had hypertension

\section{"Corresponding Authors}

Islamudin Ahmad, Department of Pharmaceutical Sciences, Faculty of Pharmacy, Mulawarman University, Samarinda, East Kalimantan, Indonesia.E-mail: islamudinahmad@farmasi.unmul.ac.id and Abdul Mun'im, Department of Pharmaceutical Sciences, Faculty of Pharmacy, Universitas Indonesia, Depok, West Java, Indonesia. E-mail:munimabdoel@gmail.com
(Mills et al., 2016) and is predicted to increase by about $60 \%$ by 2025 (Kearny et al., 2005). Also, hypertension may increase risk factors for cardiovascular disease and has been associated with complications, such as stroke, heart attack, and kidney failure (Hartmann and Meisel, 2007).

One of the primary therapeutic agents for the treatment of hypertension is angiotensin-converting enzyme (ACE) inhibitors. $\mathrm{ACE}$ is one component of the renin-angiotensin-aldosterone system and plays a crucial role in the regulation of blood pressure (Skeggs et al., 1953; 1957). Metalloprotein residue of $\mathrm{Zn}^{2+}$ in ACE cleaves the His-Leu dipeptide from the inactivated $\mathrm{C}$ angiotensin I terminal (Ang I) and converting it into a potent vasoconstrictor in the form of angiotensin II (Unger, 2002). ACE has two isoforms, 
including: (1) glycoprotein form in somatic tissue with single large polypeptide chain of 1,277 amino acid and (2) in germinal cells that are synthesized in the form of lower molecular mass and play a role in sperm maturation and sperm binding of oviduct epithelium (Natesh et al., 2003; 2004). Currently, the crystal structure data from ACE is available in the form of PDB files that can be used for in silico molecular docking study.

In recent years, modeling methods based on computer simulations have become a useful tool in solving many scientific and engineering problems (Forli et al., 2016). In some conditions, computer-based modeling methods have become a bridge between applied or experimental science and theories of natural sciences, such as physics, chemistry, and biology quickly and precisely. When the simulation is compared with the experiment, it sometimes gives slightly different results (Ramachandran et al., 2008). Molecular docking is a process that searches for possible bonds of two molecules interacting under topographical conditions or energy considerations, the goal being to match the two molecules to the conformation in which has the best interaction (Santos-Martins et al., 2014; Seeliger and de Groot, 2010). One molecule (ligand) is docked to another molecular region (receptor) and from both molecules are calculated its interaction energy. In docking, its interaction energy is calculated by Van der Waals energy and Coulombic energy involved between all the atoms of both molecules (Ghosh and Gemma, 2014).

Natural products (mainly from plants) are the primary source for new drugs discovery. One of the herbs empirically used as a hypertension drug by the community in some countries is Peperomia pellucida (L) Kunth herb. According to the study reported by Saputri et al. (2015), the methanol extract of $P$. pellucida has ACE inhibitory activity with $\mathrm{IC}_{50}$ of $7.17 \mu \mathrm{g} / \mathrm{ml}$ and (Kurniawan et al., 2016) has reported that fraction and isolated quercetin of $P$. pellucida herb has $\mathrm{IC}_{50}$ of 3.44 and $7.22 \mu \mathrm{g} / \mathrm{ml}$, respectively. Some polyphenols isolated from this herb includes secolignan (peperomins) and lignin (Xu et al., 2006), pellucidin A (Bayma et al., 2000), patuloside A (Khan et al., 2010), dillapiole (Rojas-Martínez et al., 2013), chromenes (Susilawati et al., 2015), and quercetin (Kurniawan et al., 2016). However, a study on ACE inhibitory activity (except quercetin) and the prediction of interaction conformation with ACE has not been reported.

In the present study, prediction of activity potency and interaction conformation of isolates from $P$. pellucida herbs with ACE have been conducted, which thus may expedite the development of further studies for new drugs discovery as ACE inhibitors.

\section{MATERIALS AND METHODS}

\section{Materials}

For in silico molecular docking study, a computer ASUS ${ }^{\circledR}$ (Taipei, Taiwan) with following specifications was used: processor Intel $^{\circledR}$ Core $^{\mathrm{TM}}$ i5-5200U CPU @2.20 GHz 2.19 GHz, 4.00 GB memory (RAM) DDR3, 64-bit Operating System, $\times 64$-based processor, Windows Education 10.1, and NVIDIA GEFORCE 820 M VGA. Software installed includes ChemOffice Pro v15.00 PerkinElmer, Chimera 1.10.2., Ligplot ${ }^{+}$v.1.4.5, AutoDockZn (http:// autodock.scripps.edu/resources/autodockzn-forcefield), AutoDock v4.2.6 and AutoDockTools (http://autodock.scripps.edu/), Amber14 (operated via putty to connect with the server), Pymol, OpenBabel GUI, and PMV 1.9.2 (Phyton Molecular Viewer).

\section{Receptor and native ligand structure preparation}

The crystal structure of ACE (angiotensin-converting enzyme) in complex with captopril was downloaded from Protein Data Bank (rcsb.org/pdb/) with PDB id: $1 \mathrm{UZF}$ with 2.0 Å resolution. Ligand-protein docking was performed using AutodockZn program. AutoDockTools and OpenBabel programs were used to prepare and convert the type of the macromolecule complex and ligand file (O'Boyle et al., 2011). Furthermore, water molecules were removed from the macromolecule protein $1 \mathrm{UZF}$; then the complete structure was converted, and hydrogen atom addition was done using Leap module of AMBER 14. The ligand file was subjected to the calculation of AM1-BCC partial atomic charges using antechamber module of AMBER 14 and minimization was done using Amber force field ff99SB. Then, the output (.crd) was converted to PDB by an ambpdb module of AMBER 14.

\section{Ligand sample preparation}

Structure of Ligand samples was acquired from some literature (as can be seen in Table 1) (Bayma et al., 2000; Khan et al., 2010; Kurniawan et al., 2016; Rojas-Martínez et al., 2013; Susilawati et al., 2015; Xu et al., 2006). 2D structure of ligand samples was built using ChemDraw ${ }^{\circledR}$ Pro 15 and was converted to the $3 \mathrm{D}$ structure using Chem $3 \mathrm{D}^{\circledR}$ Pro 15 . The MMFF94 atom types and charges of ligand samples were calculated, then minimization was performed using the MMFF94 force field minimization of Chem $3 \mathrm{D}^{\circledR}$ Pro 15 (Wang et al., 2015). The minimized structure was converted to PDB format.

\section{In silico molecular docking analysis}

Docking of all the ligand samples was conducted using AutoDockZn (O'Boyle et al., 2011). The program was begun with ligands in different conformations and found the best docking on binding-site proteins using a Lamarckian Genetic Algorithm (LGA) to make one possible formation. The docking simulation was performed for the isolated compound using a protein receptor (PDB id: 1UZF). The autogridZn program was used to calculate the position of the grid. Based on the active site of $\mathrm{Zn}^{2+}$, the central grid was placed on $\mathrm{Zn}^{2+}$ with a box size of $40 \hat{A} \times 40 \hat{A} \times 40 \hat{A}$ and a center of $40.835,34.382$, and 44.607 for selective inhibitors (MCO702) with a spacing of 0.375 . The docking procedure was done using autodockZn program with 100 docking runs. Docking results were visualized using $\mathrm{LigPlot}^{+}$and Poseview (Laskowski and Swindells, 2011; Stierand and Rarey, 2010).

\section{RESULTS AND DISCUSSION}

In silico molecular docking study aims to determine the potential of active compounds from natural products or synthetic. It is an approach for predicting potentially active compound based on the interaction and bonds types between the ligand and the active site of the receptor. This method is beneficial to predict the biological activity and interaction of ligand compounds quickly, accurately, and inexpensively.

In present study, in silico molecular docking study was performed to predict the potency of activity and interaction between ligand molecules in the form of native ligand (captopril) 
Table 1. The IUPAC name and chemical structure of polyphenols compound from P. pellucida.

\begin{tabular}{|c|c|c|c|}
\hline Compounds & IUPAC name & Structure formula & Ref. \\
\hline 2 & $\begin{array}{l}\text { 4-((7-methoxybenzo[d][1,3]dioxol-5-yl) } \\
\text { (3,4,5-trimethoxyphenyl)methyl)-3-methyldihydrofuran- } \\
\text { 2(3H)-one (secolignan) }\end{array}$ & & (Xu et al., 2006) \\
\hline 3 & $\begin{array}{l}\text { ((1S,2R,3R,5S)-3-(4-hydroxy-3,5-dimethoxyphenyl)-2- } \\
\text { (hydroxymethyl)-5-(7-methoxybenzo[d][1,3]dioxol-5-yl) } \\
\text { cyclopentyl)methyl acetate (tetrahydrofuran lignin) }\end{array}$ & & (Xu et al., 2006) \\
\hline 4 & $\begin{array}{l}\text { ((1R,2S,3S,5R)-3,5-bis(4-hydroxy-3,5-dimethoxyphenyl) } \\
\text { cyclopentane-1,2-diyl)bis(methylene) diacetate } \\
\text { (tetrahydrofuran lignin) }\end{array}$ & & (Xu et al., 2006) \\
\hline 5 & $\begin{array}{l}\text { 5,6,7-trimethoxy-4-(2,4,5-trimethoxyphenyl)- } \\
\text { 3,4-dihydronaphthalen-1(2H)-one (methoxylated } \\
\text { dihydronaphthalenone) }\end{array}$ & & (Xu et al., 2006) \\
\hline 6 & $\begin{array}{l}\text { 1,5,6-trihydroxy-3-((2S,3S,4S,5S,6S)-3,4,5-trihydroxy-6- } \\
\text { (hydroxymethyl)tetrahydro-2H-pyran-2-yl)-9H-xanthen-9-one } \\
\text { (Patuloside A) }\end{array}$ & & (Khan et al., 2010) \\
\hline 7 & 6-allyl-4,5-dimethoxybenzo[d][1,3]dioxole (dillapiole) & & (Rojas-Martínez et al., 2013 \\
\hline 8 & $\begin{array}{l}\text { (S)-2-methyl-2-(4-methylpent-3-en-1-yl)-6-(propan-2- } \\
\text { ylidene)-3,4,6,7-tetrahydropyrano[4,3-g]chromen-9(2H)-one } \\
\text { (Chromene) }\end{array}$ & & (Susilawati et al., 2015) \\
\hline 9 & $\begin{array}{l}\text { 2-(3,4-dihydroxyphenyl)-3,5-dimethoxy-7-((3,4,5-trihydroxy- } \\
\text { 6-methyltetrahydro-2H-pyran-2-yl)oxy)chroman-4-one } \\
\text { (quercetin) }\end{array}$ & & (Kurniawan et al., 2016) \\
\hline
\end{tabular}


and the isolated polyphenol compounds of P. pellucida (consisting of nine compounds as listed in Table 1) on the ACE macromolecule (PDB id: 1UZF).

The docking of native ligand (captopril) gave Root Mean Square Deviation (RMSD) value of $0.96 \mathrm{~A}(<2)$, which means the docking results were valid with a $\Delta G$ value of -6.36 and clusters of $92 \%$ for the total of 100 times running. As can be seen in Figure 1, it shows the position between the native ligand and the docking results does not show significantly different locations

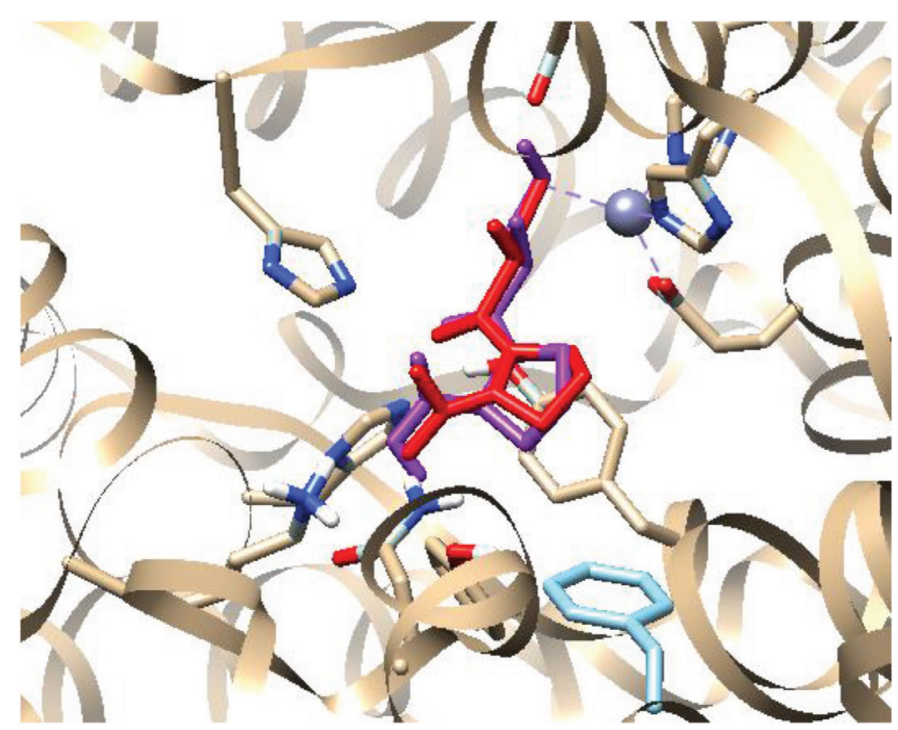

Figure 1. Visualization of comparison between original and docking results position of the native ligand. Where a red is original crystallography and purple is docking results. (with the RSMD value $<2$ ). Figure 2 demonstrates the interaction between groups of the native ligand with protein (amino acid) and $\mathrm{Zn}^{2+}$ metalloprotein groups of an ACE macromolecule using LigPlus (A), PoseView (B). The binding mode of captopril in ACE macromolecule complex was investigated from its crystal structure (ID $1 \mathrm{UZF}$ ). It is shown that the $\mathrm{COOH}$ and $\mathrm{C}=\mathrm{O}$ groups of captopril formed hydrogen bonds with Tyr520, Lys511, Gln281 (with $\mathrm{COOH}$ ) and His353, His513 (with $\mathrm{C}=\mathrm{O}$ ), respectively. The $\mathrm{S}-\mathrm{H}$ group formed interaction with metalloproteins $\mathrm{Zn}^{2+}$ (with an atomic distance of $2.3 \AA$ ) and formed hydrogens bonding with Glu384. The bond forms of ligands from the docking results involved the hydrogen and hydrophobic bonds on clusters of amino acids and its interactions in the $\mathrm{Zn}^{2+}$ metalloprotein according to studies has been reported by Chang and Alli (2012) and Sharifi et al. (2013). This interaction (with distances of $<3 \AA$ ) indicated that the active site of each ligand has interaction with ACE macromolecule. In Figure 3, the binding mode of each compound in macromolecule demonstrated that the groups of each compound (except Compound 8) formed interaction with $\mathrm{Zn}^{2+}$ and Glu384. Meanwhile, His353, His513, and Tyr523 had interactions (hydrogen and hydrophobic bond) with groups of each compound, and another hand, another amino acid group had different interactions.

Meanwhile, Table 2 demonstrates that the prediction of polyphenols compound from $P$. pellucida has potential to be developed as ACE inhibitors, it was indicated that docking results of each compound have lower affinity than captopril (with a binding affinity of $-6.36 \mathrm{kcal} / \mathrm{mol}$ and the inhibition constant $21.81 \mu \mathrm{M}$ ) except Compound 7. Based on the results of calculation and docking analysis, similarity was exhibited between polyphenol compounds (except compound 7) with the native ligand. In the previous study, Guerrero et al. (2012) have predicted the interaction and bonds of luteolin (polyphenols

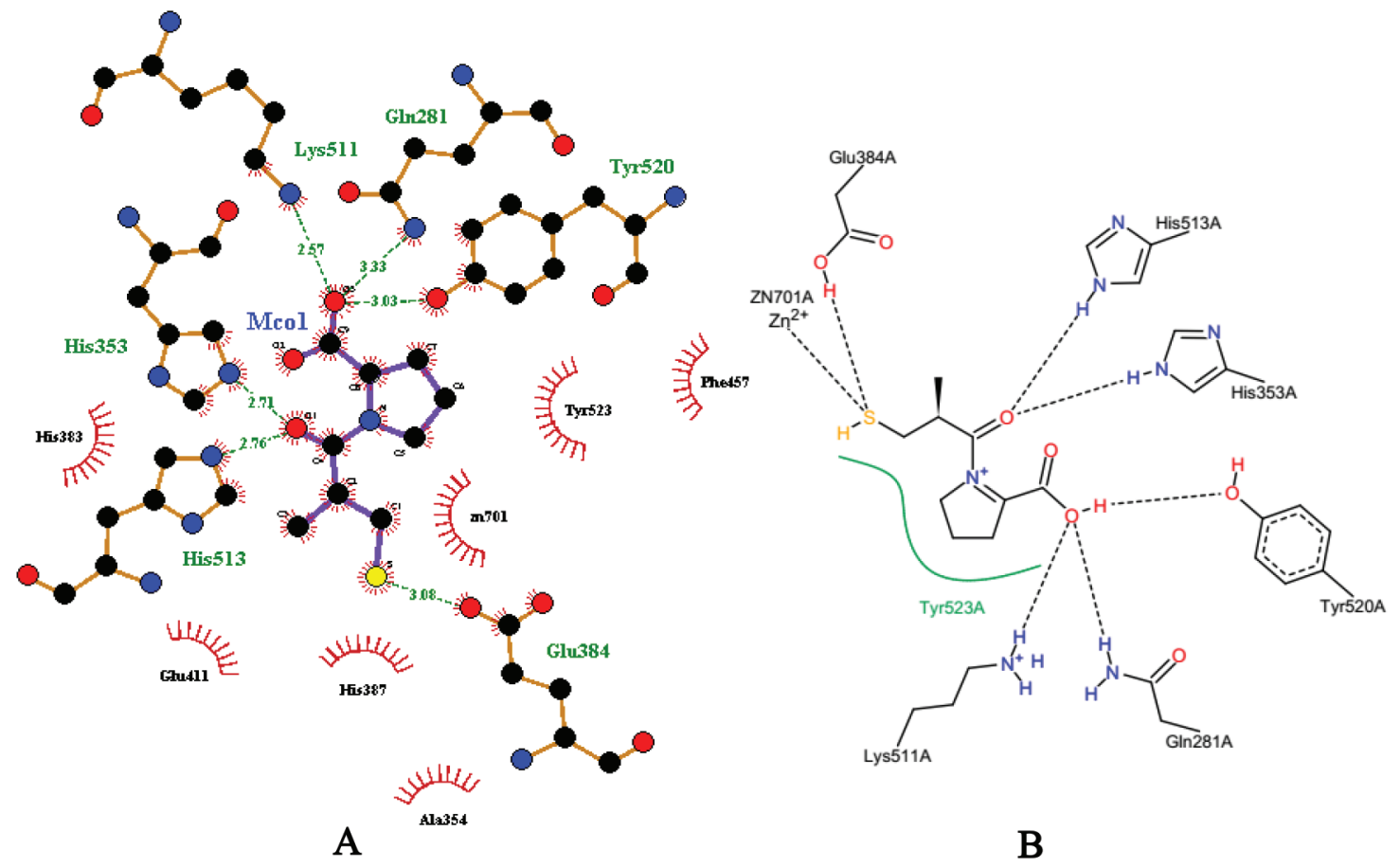

Figure 2. Visualization of docking results interaction between the native ligand and residue of ACE macromolecule (PDB: 1UZF) using (A) Ligplotplus and (B) dan Poseview. 
group) using QSAR and molecular docking study of quercetin as a potential ACE inhibitor has been reported by Muhammad and Fatima (2015). Each amino acid residue can form seven different bonds or interactions with the ligand includes: (1) interaction of van der Waals bond, (2) interaction of aromatic face to face, (3) interaction of aromatic edge to face, (4) interaction of H-bond or protein as donor, (5) interaction of $\mathrm{H}$-bond or protein as acceptor, (6) interaction of protein positively charged, and (7) interaction of protein negatively charged (Radifar et al., 2013). In addition, Table 2 also shows that some compounds have a potential active site with interaction distance between $\mathrm{O}$ atoms (ligand groups) and $\mathrm{Zn}^{2+}$ metalloprotein (protein receptor residue) at values less than $3 \AA$, includes Compound 3, Compound 4, Compound 5, Compound 6, Compound 8, and Compound 9 with constant inhibition 752.52, $448.43,10,740,2,470,517.42$, and $831.04 \mathrm{nM}$, respectively. On other hands, $\mathrm{Zn}^{2+}$, Glu384, His513, His353, Gln281, Tyr520,
Tyr523, and Lys511 are the binding site of ACE. The native ligand of captopril performs hydrogen bonding $\left(\mathrm{Zn}^{2+}\right.$, Glu384, His513, His353, Gln281, Tyr520, and Lys511) and hydrophobic interaction (Tyr523). Based on the results of docking analysis, compound 5 has the most similar interaction with the captopril ligand where the compound binds to the active side of ACE as can be seen in Table 2, and these prediction results are in accordance with the molecular docking results of polyphenol compounds from Phyllanthus niruri herbs (Ahmad et al., 2018). In addition, some study has reported that extracts and fractions (with rich in polyphenol content) of this herbs have activity as an ACE inhibitor using in vitro assay method (Adhitia et al., 2017; Mun'im et al., 2017; Rinayanti et al., 2013; Saputri et al., 2015). Meanwhile, according to the previous study, Kurniawan et al. (2016) have done the assay of ACE inhibitory activity of Compound 9 (quercetin) with $\mathrm{IC}_{50}$ of 16.21 $\mathrm{nM}$ which has excellent correlation with the obtained docking

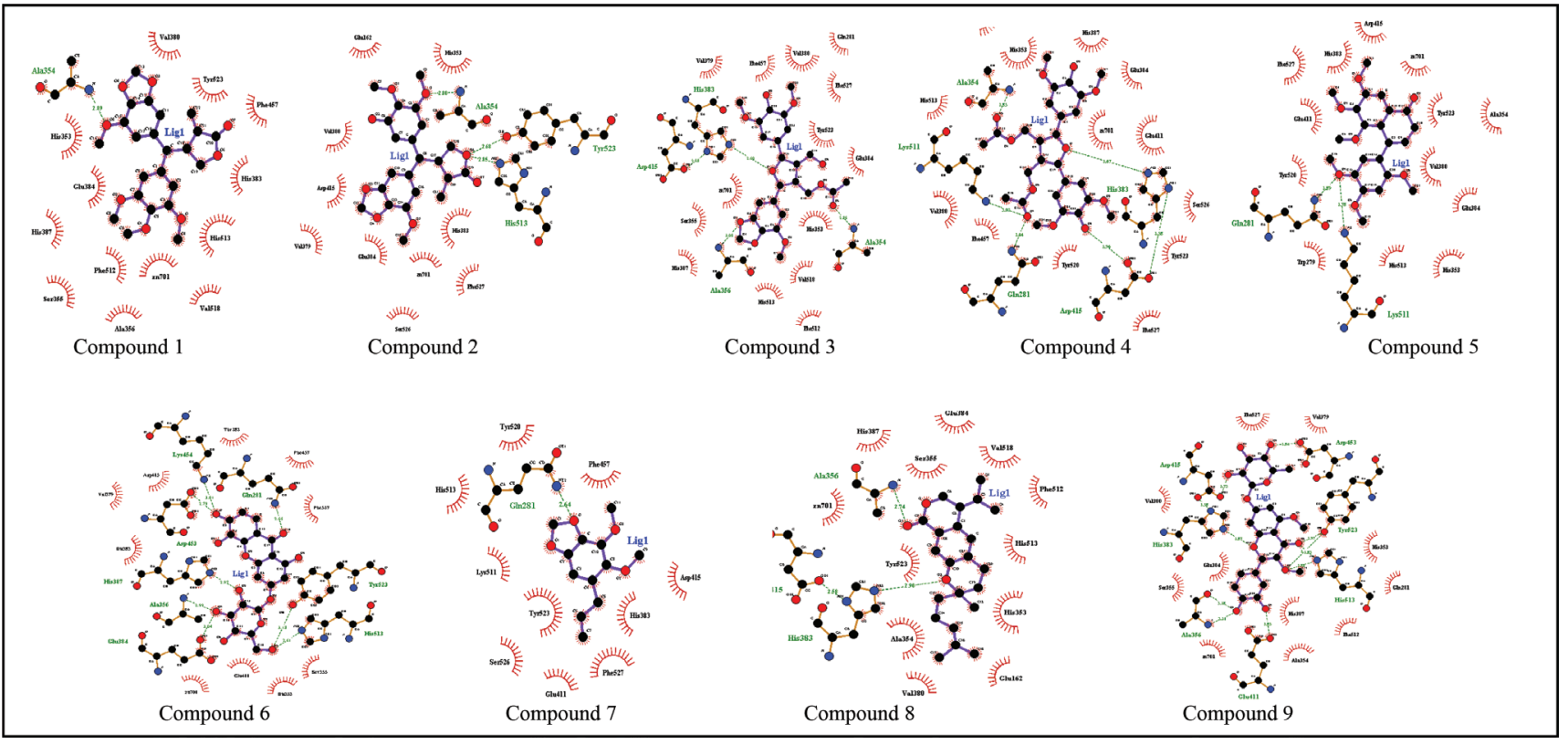

Figure 3. Visualization of docking results interaction of isolated polyphenols from P. Pellucida and ACE macromolecule receptor (PDB: 1UZF) by Ligplotplus software.

Table 2. The docking results of captopril and polyphenol compounds from P. pellucida.

\begin{tabular}{|c|c|c|c|c|c|c|c|c|c|c|c|c|}
\hline \multirow{2}{*}{ No } & \multirow{2}{*}{ Ligand } & \multirow{2}{*}{$\begin{array}{c}\text { Binding energy } \\
\text { (kcal/mol) }\end{array}$} & \multirow{2}{*}{$\begin{array}{c}\text { Inhibition } \\
\text { constant (nM) }\end{array}$} & \multirow{2}{*}{$\begin{array}{c}\text { Atom distances } \\
\text { Zn-S/O }(\AA)\end{array}$} & \multicolumn{8}{|c|}{ Interaction of ACE binding site } \\
\hline & & & & & $\mathbf{Z n}^{2+}$ & Glu384 & His513 & His353 & Gln281 & Tyr520 & Tyr523 & Lys511 \\
\hline 1 & Captopril (Native) & - & - & - & $\sqrt{ }$ & $\sqrt{ }$ & $\sqrt{ }$ & $\sqrt{ }$ & $\sqrt{ }$ & $\sqrt{ }$ & $\sqrt{ }$ & $\sqrt{ }$ \\
\hline 2 & Captopril redocked & -6.36 & 21,810 & 2.3 & $\sqrt{ }$ & $\sqrt{ }$ & - & $\sqrt{ }$ & $\sqrt{ }$ & $\sqrt{ }$ & $\sqrt{ }$ & $\sqrt{ }$ \\
\hline 3 & Compound 1 & -8.08 & 1,190 & 3.3 & $\sqrt{ }$ & $\sqrt{ }$ & - & $\sqrt{ }$ & - & - & $\sqrt{ }$ & - \\
\hline 4 & Compound 2 & -8.14 & 1,080 & 4.7 & $\sqrt{ }$ & $\sqrt{ }$ & - & $\sqrt{ }$ & - & - & $\sqrt{ }$ & - \\
\hline 5 & Compound 3 & -8.35 & 752.52 & 2.7 & $\sqrt{ }$ & $\sqrt{ }$ & - & $\sqrt{ }$ & $\checkmark$ & - & $\sqrt{ }$ & - \\
\hline 6 & Compound 4 & -8.66 & 448.43 & 2.2 & $\sqrt{ }$ & $\sqrt{ }$ & - & $\sqrt{ }$ & $\sqrt{ }$ & - & $\sqrt{ }$ & - \\
\hline 7 & Compound 5 & -6.78 & 10,740 & 2.7 & $\sqrt{ }$ & $\sqrt{ }$ & $\sqrt{ }$ & - & $\sqrt{ }$ & $\sqrt{ }$ & $\sqrt{ }$ & $\sqrt{ }$ \\
\hline 8 & Compound 6 & -7.65 & 2,470 & 2.1 & $\sqrt{ }$ & $\sqrt{ }$ & $\sqrt{ }$ & $\sqrt{ }$ & $\sqrt{ }$ & - & $\sqrt{ }$ & - \\
\hline 9 & Compound 7 & -4.99 & 218,680 & 6.2 & - & - & - & - & $\sqrt{ }$ & $\sqrt{ }$ & $\sqrt{ }$ & $\checkmark$ \\
\hline 10 & Compound 8 & -8.58 & 517.42 & 2.9 & $\sqrt{ }$ & $\sqrt{ }$ & - & $\sqrt{ }$ & - & - & $\sqrt{ }$ & - \\
\hline 11 & Compound 9 & -8.30 & 831.04 & 2.8 & $\sqrt{ }$ & $\sqrt{ }$ & $\sqrt{ }$ & $\sqrt{ }$ & $\sqrt{ }$ & - & $\sqrt{ }$ & - \\
\hline
\end{tabular}


result. Therefore, it is essential to proceed to further study, mainly isolation and identification of active compounds as ACE inhibitors of this plant.

\section{CONCLUSION}

In conclusion, we have conducted in silico molecular docking to study the potential of polyphenol compounds from $P$. pellucida as an ACE inhibitor. The crystal structure of ACE (PDB id: IUZF) bound to captopril was used as a protein target. Based on the docking result showed that the native ligand (captopril) was obtained RMSD value of $0.96 \hat{A}(<2)$, which means the docking results were valid with a $\Delta G$ value of -6.36 and clusters of $92 \%$ for the total of 100 times running. Based on the interaction of ACE binding site, Compound 5 shows the most similar interaction with the captopril ligand where the compound binds to the active side of ACE compared to other compounds. Therefore, these results are preliminary data for further research with predictions of biological activity and interaction quickly, accurately, and inexpensively from the target compound.

\section{ACKNOWLEDGMENT}

This study was funded by Directorate of Research and Humanity Engagement (DRPM), Universitas Indonesia via "Hibah Tugas Akhir Mahasiswa Doktor Tahun 2018.”

\section{CONFLICT OF INTEREST}

All author declared that there is no conflict of interest

\section{ABBREVIATIONS}

ACE: Angiotensin-Converting Enzyme; DRPM: Direktorat Riset dan Pengabdian kepada Masyarakat; Gln: Glutamine; Glu: Glutamate; His: Histidine; $\mathrm{IC}_{50}$ : half maximal inhibitory concentration; LGA: Lamarckian Genetic Algorithm; Lys: Lysine; MMFF94: Merck Molecular Force Field 94; $P$. pellucida: Peperomia pellucida (L) Kunth; PDB: Protein Data Bank; RMSD: Root Mean Square Deviation; Tyr: Tyrosine.

\section{REFERENCES}

Adhitia AM, Octaviani AN, Rissyelly, Basah K, Mun'im A. Effect of gamma irradiation on angiotensin-converting enzyme inhibition, antioxidant activity, total phenolic compound and total flavonoid of Peperomia pellucida herbs extract. Pharmacogn J, 2017; 9:244-8.

Ahmad I, Mun'im A, Luliana S, Elya B, Azminah A, Yanuar A, Artha Y, Negishi O. Isolation, elucidation, and molecular docking studies of active compounds from Phyllanthus niruri with angiotensin-converting enzyme inhibition. Pharmacogn Mag, 2018; 14:601-10.

Bayma JDC, Arruda MSP, Muller AH, Arruda AC, Canto WC. A dimeric ArC2 compound from Peperomia pellucida. Phytochemistry, 2000; 55:779-82.

Chang YW, Alli I. In silico assessment: suggested homology of chickpea (Cicer arietinum L.) legumin and prediction of ACE-inhibitory peptides from chickpea proteins using BLAST and BIOPEP analyses. Food Res Int, 2012; 49:477-86.

Forli S, Huey R, Pique ME, Sanner MF, Goodsell DS, Olson AJ. Computational protein-ligand docking and virtual drug screening with the Autodock suite. Nat Protoc, 2016; 11:905-19.

Ghosh AK, Gemma S. Structure-based design of drugs and other bioactive molecules: tools and strategies.WILEY-VCH Verlag GmbH \& Co. KGaA, Weinheim, Weinheim, Germany, 2014.

Guerrero L, Castillo J, Quinones M, Garcia-Vallve S, Arola L, Pujadas G, Muguerza B. Inhibition of angiotensin-converting enzyme activity by flavonoids: structure-activity relationship studies. PLoS One, 2012; 7:1-11.
Hartmann R, Meisel H. Food-derived peptides with biological activity: from research to food applications. Curr Opin Biotechnol, 2007; 18:163-9.

Kearny PM, Whelton M, Reynolds K, Munther P, Whelton PK, He J. Global burden of hypertension: analysis of worldwide data. Lancet, $2005 ; 365: 217-23$.

Khan A, Rahman M, Islam S. Isolation and bioactivity of a xanthone glycoside from Peperomia pellucida. Life Sci Med Res, 2010; 2010:1-10

Kurniawan A, Saputri FC, Rissyelly, Ahmad I, Mun'im A. Isolation of angiotensin-converting enzyme (ACE) inhibitory activity quercetin from Peperomia pellucida. Int J PharmTech Res, 2016; 9:115-21.

Laskowski RA, Swindells MB. LigPlot ${ }^{+}$: multiple ligand À protein interaction diagrams for drug discovery. J Chem Inf Model, 2011; 51:2778-86.

Mills KT, Bundy JD, Kelly TN, Reed JE, Kearny PM, Reynolds $\mathrm{K}$, Chen J, He J. Global disparities of hypertension prevalence and control. Circulation, 2016; 134:441-50.

Muhammad SA, Fatima N. In silico analysis and molecular docking studies of potential angiotensin-converting enzyme inhibitor using quercetin glycosides. Pharmacogn Mag, 2015; 11:123-6.

Mun'im A, Nurpriantia S, Setyaningsih R, Syahdi RR Optimization of microwave-assisted extraction of active compounds, antioxidant activity and angiotensin-converting enzyme (ACE) inhibitory activity from Peperomia pellucida (L.) Kunth. J Young Pharm, 2017; 9:168-71.

Natesh R, Schwager SLU, Sturrock ED, Acharya KR. Crystal structure of the human enzyme-lisinopril complex. Nature, 2003; 421:1427-9.

Natesh R, Schwager SLU, Evans HR, Sturrock ED, Acharya KR. Structural details on the binding of antihypertensive drugs captopril and enalaprilat to human testicular angiotensin I-converting enzyme. Biochemistry, 2004; 43:8718-724.

O'Boyle NM, Banck M, James CA, Morley C, Vandermeersch T, Hutchison GR. Open Babel: an open chemical toolbox. J Cheminform, 2011; 3:1-14

Radifar M, Yuniarti N, Istyastono EP. PyPLIF: python-based protein-ligand interaction fingerprinting. Bioinformation, 2013; 9:325-8.

Ramachandran KI, Deepa G, Namboori K. Computational chemistry and molecular modeling.Springer Berlin Heidelberg, Berlin, Heidelberg, 2008

Rinayanti A, Radji M, Mun'im A, Suyatna FD. Screening angiotensin-converting enzyme (ACE) inhibitor activity of antihypertensive medicinal plants from Indonesia. Int J Pharm Teach Pract, 2013; 4:527-32.

Rojas-Martínez R, Arrieta J, Cruz-Antonio L, Arrieta-Baez D, Velazquez-Mendez AM, Sanchez-Mendoza ME. Dillapiole, isolated from Peperomia pellucida, shows gastroprotector activity against ethanolinduced gastric lesions in wistar rats. Molecules, 2013; 18:11327-37.

Santos-Martins D, Forli S, Ramos MJ, Olson AJ. AutoDock4Zn: an improved AutoDock force field for small-molecule docking to zinc metalloproteins. J Chem Inf Model, 2014; 54:2371-9.

Saputri FC, Mun'im A, Lukmanto D, Aisyah SN, Rinandy JS Inhibition of angiotensin-converting enzyme (ACE) activity by some Indonesia edible plants. Int J Pharm Sci Res, 2015; 6:1054-9.

Seeliger D, de Groot BL. Ligand docking and binding site analysis with PyMOL and Autodock/Vina. J Comput Aided Mol Des, 2010; $24: 417-22$.

Sharifi N, Souri E, Ziai SA, Amin G, Amini M. Isolation, identification and molecular docking studies of a new isolated compound, from Onopordon acanthium: a novel Angiotensin Converting Enzyme (ACE) inhibitor. J Ethnopharmacol, 2013; 148:934-9.

Skeggs LT, Marsh WH, Kahn JR, Shumway NP. The existence of two forms of hypertension. J Exp Med, 1953; 99:275-82.

Skeggs LT, Kahn JR, Lentz K, Shumway NP. The preparation, purification, and amino acid sequence of a polypeptide renin substrate. $J$ Exp Med 1957; 106:439-53. 
Sorlie PD, Allison MA, Aviles-Santa ML, Cai J, Daviglus ML, Howard AG, Kaplan R, LaVange LM, Raij L, Schneiderman N, WassertheilSmoller S, Talavera GA. Prevalence of hypertension, awareness, treatment, and control in the Hispanic community health study/study of Latinos. Am J Hypertens, 2014; 27:793-800.

Stierand K, Rarey M. PoseView-molecular interaction patterns at a glance. J Cheminform, 2010; 2:P50.

Susilawati Y, Nugraha R, Muhtadi A, Soetardjo S, Supratman U. (S)-2-Methyl-2-(4-methylpent-3-enyl)-6-(propan-2-ylidene)-3,4,6,7tetrahydropyrano[4,3-g]chromen-9(2H)-one. Molbank, 2015; 2015:M855.

Unger $\mathrm{T}$. The role of the renin-angiotensin system in the development of cardiovascular disease. Am J Cardiol, 2002; 89:3-9.

Wang L, Wu Y, Deng Y, Kim B, Pierce L, Lupyan D, Robinson S, Dahlgren MK, Greenwood J, Romero DL, Masse C, Knight JL, Steinbrecher T, Beuming T, Damm W, Harder E, Sherman W, Brewer M, Wester R, Murcko M, Frye L, Farid R, Lin T, Mobley DL, Jorgensen WL,
Berne BJ, Friesner RA, Abel R. Accurate and reliable prediction of relative ligand binding potency in prospective drug discovery by way of a modern free-energy calculation protocol and force field. J Am Chem Soc, 2015; 137:2695-703

Xu S, Li N, Ning MM, Zhou CH, Yang QR, Wang MW. Bioactive compounds from Peperomia pellucida. J Nat Prod, 2006; 69:247-50.

\section{How to cite this article:}

Ahmad I, Azminah A, Mulia K, Yanuar A, Mun'im A. Angiotensin-converting enzyme inhibitory activity of polyphenolic compounds from Peperomia pellucida (L) Kunth: An in silico molecular docking study. J Appl Pharm Sci, 2019; 9(08):025-031. 